\title{
Genistein Suppresses TPA-Induced Matrix Metalloproteinases Activity and Cell Invasion in Human Breast Adenocarcinoma Cells
}

\author{
Yung Hyun Choi ${ }^{1}$ and Sung Ok Kim² \\ ${ }^{1}$ Department of Biochemistry, College of Oriental Medicine, Department of Biomaterial Control (BK21 program), Anti-Aging Research Center \& \\ Blue-Bio Industry RIC, Dongeui University, Busan 614-052, Korea \\ ${ }^{2}$ Department of Herbal Pharmacology of Oriental Medicine, College of Oriental Medicine \& R\&D Team for the New Drug of Oriental Medicine \\ (BK21), Daegu Hanny University, Daegu 706-828, Korea
}

Received April 30, 2012 /Revised May 16, 2012 /Accepted July 19, 2012

\begin{abstract}
Genistein, a predominant isoflavone, has been shown to inhibit the growth of various cancer cells in vitro and in vivo without toxicity to normal cells. In the present study, we investigated the effects of genistein on the activity and the expression of matrix metalloproteinases (MMPs) in MCF-7 and MDA-MB-231 human breast adenocarcinoma cells. Our findings showed that MMP-9 and -2 activation was significantly increased in response to 12 - $O$-tetradecanoyl phorbol-13-acetate (TPA). However, the increased activities of MMP-9 and -2 in TPA-treated cells were concentration-dependently inhibited by treatment with genistein, and this was also correlated with a decrease in the expression of their mRNA and proteins. In addition, a matrigel invasion assay showed that genistein reduced TPA-induced invasion of MCF-7 and MDA-MB-231 cells. Although further in vivo studies are needed, these results suggest that genistein treatment may inhibit tumor cell invasion and, therefore, act as a dietary source to decrease the risk of cancer metastasis.
\end{abstract}

Key words : Genistein, breast cancer, 12-O-tetradecanoyl phorbol-13-acetate (TPA), matrix metalloproteinases (MMPs), invasion

\section{서 론}

최근 의생명과학의 발전에 의한 암 환자의 수명과 삶의 질 이 현저히 개선된 것은 사실이나 여전히 암에 의한 사망률이 높은 편이며, 이러한 사망의 주된 원인은 암세포의 전이 (metastasis)에 의해서 유발된다. 따라서 암세포의 이동 (migration)이나 침윤(invasion)을 억제하는 기전의 규명이나 효과적인 치료 약물 개발이 많은 연구자들의 주된 표적이 되 고 있다. 암세포의 침윤과 전이는 암의 진행에서 나타나는 기 본적인 과정으로 extracellular matrix $(\mathrm{ECM})$ 와 기저막 (basement membrane)을 포함한 tissue barrier들의 붕괴를 포 함한 다양한 세포생리학적 변화를 동반한다. 그리고 $\mathrm{ECM}$ 의 붕괴와 재구성(remodeling)에는 matrix metalloproteinases (MMPs)와 같은 단백질 분해효소들의 활성이 요구된다[22, 24, 29]. MMPs는 zinc-dependent한 protein-degrading endopeptidase들로서, 현재 28가지가 밝혀져 있으며 collagenases (MMP-1, MMP-8 및 MMP-13), gelatinases (MMP-2 및 MMP-9), stromelysins (MMP-3, MMP-10, MMP-11 및 MMP-7), matrilysins와 membrane-type MMPs (MMP-14, MMP-15, MMP-16 및 MMP-17) 등으로 분류되고 있다[7,12]. $\mathrm{MMP}$ family 인자들은 발생과정이나 혈관신생(angiogenesis)

*Corresponding author

Tel : +82-51-850-7413, Fax : +82-51-853-4036

E-mail : choiyh@deu.ac.kr
및 상처 치료(wound healing) 등을 포함한 정상적인 생물학적 기능의 수행에 중요한 요소들이다. 이들은 또한 종양 침윤 (tumor invasion), 아테롬성 동맥 경화(atherosclerosis), 염증 (inflammation) 및 류마티스 관절염(rheumatoid arthritis) 등 과 같은 병리적 현상의 진행에 중요한 작용을 한다 $[2,6,13]$. 특히 MMP-2 (gelatinase-A, $72 \mathrm{kDa}$ )와 MMP-9 (gelatinase-B, $92 \mathrm{kDa}$ )는 type IV collagen의 분해에 중요한 역할을 하며 구 조적으로나 효소 활성적 유사성을 지닌다. 많은 조직에서 기 본적으로 발현되는 MMP-2는 tissue inhibitor of metalloproteinase (TIMP)-2와의 상호작용에 의한 전사후 수준 (post-transcriptional level)에서 조절되는 반면, MMP-9는 growth factors (fibroblast growth factor-2, epidermal growth factor 및 hepatocyte growth factor), cytokines (tumor necrosis factor-a) 또는 12-O-tetradecanoylphorbol-13-acetate (TPA) 등과 같은 화합물에 의하여 전사 수준에서 발현이 조절 된다[4,14,32].

Genistein은 soy isoflavone의 주요 bioactive component로 서 in vitro 및 in vivo 수준에서 다양한 암세포의 증식을 억제하 는 반면 정상세포에서의 세포독성은 상대적으로 매우 미비한 것으로 알려져 있다 $[1,3,5]$. 특히 genistein에 의한 암세포의 증 식억제는 암세포의 분화 유도, 세포주기 G2/M arrest 및 apoptosis 유도와 밀접한 연관성이 있는 것으로 알려져 왔다 [8,9,16,18-20,26,33]. 또한 genistein은 유방암을 포함한 어떤 암 세포에서 침윤성(invasive potential)의 억제를 통한 암세포 전 
이 억제 효능이 탁월한 것으로 알려져 있다 $[11,15,21,27,28,30]$. 그러나 TPA와 같은 인위적인 종양 촉진 인자들에 의한 암세 포의 침윤성 증가에 미치는 영향을 잘 알려져 있지 않다. 따라 서 본 연구에서는 TPA를 이용한 인체유방암세포 모델에서 genistein의 침윤성 활성 여부를 조사하였다.

\section{재료 및 방법}

\section{암세포의 배양 및 genistein의 처리}

본 실험에 사용한 MCF-7 및 MDA-MB-231 인체유방암세포 는 American Type Culture Collection (Rockville, MD, USA) 에서 분주 받아 사용하였으며, 암세포의 배양을 위해 $90 \%$ 의 Dulbecco's Modified Eagle Medium (DMEM, Gibco BRL, Grand Island, NY, USA), 10\%의 우태아혈청(fetal bovine serum, FBS), $1 \%$ 의 penicillin 및 streptomycin (Biofluids, Rockville, $\mathrm{MD}, \mathrm{USA}$ )이 포함된 성장배지를 사용하여 $37^{\circ} \mathrm{C}$, $5 \% \mathrm{CO}_{2}$ 조건 하에서 배양하였다. Genistein 및 TPA는 Sigma Chemical Co. (St. Louis, MO, USA)에서 구입하여 dimethyl sulfoxide (DMSO)를 이용하여 적정 농도의 stock solution으 로 만든 후, 적정농도로 배지에 희석하여 처리하였다.

\section{MTT assay}

Genistein과 TPA의 단독 혹은 혼합처리가 유방암세포의 증 식에 미치는 영향을 조사하기 위하여 세포 배양용 6 well plate 에 암세포를 $1 \times 10^{4}$ 개/ml로 분주하여 안정화 시킨 다음 genistein과 TPA를 각 well 당 적정농도로 처리하였다. 24시간 경과 후 $0.5 \mathrm{mg} / \mathrm{ml}$ 농도의 tetrazolium bromide salt (MTT, Amresco, Solon, $\mathrm{OH}, \mathrm{USA})$ 를 $2 \mathrm{ml}$ 씩 분주하고 2시간 동안 $\mathrm{CO}_{2}$ incubator에서 배양시킨 다음 MTT 시약을 깨끗하게 제거 하고 $\mathrm{DMSO}$ 를 $1 \mathrm{ml}$ 씩 분주하여 well에 생성된 formazin을 모두 녹인 후 96 well plate에 200 씨씩 옮겨서 ELISA reader (Molecular Devices, Sunnyvale, CA, USA)로 $540 \mathrm{~nm}$ 에서 흡 광도를 측정하였다. 측정은 모두 세 번을 하였으며, 그에 대한 평균값과 표준 오차를 Microsoft EXCEL program을 사용하여 분석하였다.

\section{In vitro invasiveness assay}

$\mathrm{TPA}$ 에 의하여 유도된 유방암세포의 침윤성 증가에 미치 는 genistein의 영향을 알아보기 위하여, matrigel을 통한 세 포 침윤성을 측정하였다. 이를 위하여 Transwell $(8 \mu \mathrm{m}$ pore; Millipore, Billerica, MA, USA)의 upper chamber를 $37^{\circ} \mathrm{C}$ 에 서 15 분간 $100 \mathrm{\mu g} / \mathrm{cm}^{2}$ 의 matrigel로 코팅하였으며, 그 후 10 분간 상온에 방치하였다. 적정 농도의 genistein과 TPA가 단 독 혹은 혼합처리된 세포 $\left(2 \times 10^{5}\right)$ 를 upper well에 첨가하였으 며, lower well은 FBS가 첨가되지 않은 DMEM으로 채웠다. 24시간 동안 배양한 후, membrane의 upper side에 있는 세
포를 제거하고 이를 methanol로 고정시키고 hematoxylin/ $\operatorname{eosin}$ 로 염색하여 200배 현미경 시야에서 계수하여 비교하였다.

Gelatin zymography를 이용한 MMP-2 및 MMP-9의 효소활성 조사

적정농도의 genistein과 TPA을 단독 혹은 혼합처리된 배지 에서 유방암세포를 24시간 동안 배양한 다음 배지를 수거하여 $0.25 \mathrm{mg} / \mathrm{ml}$ 의 젤라틴이 함유된 sodium dodecyl sulphate (SDS)-polyacrylamide gel에서 전기영동 하였다. 전기영동이 끝난 gel을 washing buffer $(50 \mathrm{mM}$ Tris-Cl pH 7.5, $10 \mathrm{mM}$ $\mathrm{CaCl}_{2}, 2.5 \%$ Triton X-100, $1.0 \mu \mathrm{M} \mathrm{ZnCl}$ )로 세척하고 incubation buffer ( $50 \mathrm{mM}$ Tris-Cl pH 7.5, $0.15 \mathrm{NaCl}, 10 \mathrm{mM}$ $\mathrm{CaCl}_{2}, 0.02 \% \mathrm{NaN}_{3}$ )에 넣어 $37^{\circ} \mathrm{C}$ 에서 24 시간 동안 반응시킨 다음, $0.1 \%$ Coomassie brilliant blue로 염색하고 확인하였다.

\section{Western blot analysis에 의한 단백질 발현의 분석}

상기와 동일한 조건에서 배양된 유방암세포에 적당량의 lysis buffer $[25 \mathrm{mM}$ Tris-Cl pH 7.5, $250 \mathrm{mM} \mathrm{NaCl}, 5 \mathrm{mM}$ EDTA, 1\% NP-40, $1 \mathrm{mM}$ phenymethylsulfonyl fluoride (PMSF), $5 \mathrm{mM}$ dithiothreitol (DTT)]를 첨가하여 $4{ }^{\circ} \mathrm{C}$ 에서 1시 간 동안 반응시킨 후, 원심분리하여 상층액에 있는 단백질을 분리하였다. 상층액의 단백질 농도는 Bio-Rad 단백질 정량 시 약(Bio-Rad, Hercules, CA, USA)을 이용하여 정량 한 다음 동 량의 sample을 SDS-polyacrylamide gel을 이용하여 전기영동 으로 분리한 후, nitrocellulose membrane (Schleicher and Schuell, Keene, NH, USA)으로 electroblotting에 의해 전이시 켰다. 분리된 단백질이 전이된 nitrocellulose membrane을 $5 \%$ skim milk를 처리하여 비특이적인 단백질들에 대한 blocking 을 실시하고 MMP-2 및 -9 항체(Santa Cruz Biotechnology Inc., Santa Cruz, CA, USA)를 처리하여 $4^{\circ} \mathrm{C}$ 에서 over night 시킨 다음 PBS-T로 세척하고 peroxidase-labeled donkey anti-rabbit immunoglobulin 및 peroxidase-labeled sheep anti-mouse immunoglobulin (Amersham Life Science Corp., Arlington Heights, IL, USA)을 상온에서 1시간 정도 반응시켰 다. 반응이 끝난 후 enhanced chemiluminoesence (ECL) solution (Amersham Life Science Corp.)을 적용시켜 X-ray film 에 감광시켜 특정단백질의 발현 양을 분석하였다.

Rverse transcriptase-polymerase chain reaction
(RT-PCR)에 의한 mRNA의 분석
동일한 조건에서 준비된 유방암세포를 대상으로 TRIzol reagent (Invitrogen Co., Carlsbad, CA, USA)을 이용하여 total $\mathrm{RNA}$ 를 분리하였다. 분리된 RNA를 정량한 후 MMP-2 및 -9의 primer (Table 1), DEPC water 그리고 ONE-STEP RT-PCR PreMix Kit (Intron, Korea)를 넣고 Mastercycler gradient (Eppendorf, Hamburg, Germany)를 이용하여 증폭하였다. 각 PCR 산물들을 양적 차이를 확인하기 위하여 1X TAE buffer로 $1 \%$ agarose gel을 만들고 well 당 각각 primer에 해당하는 
Table 1. Gene-specific primers for RT-PCR

\begin{tabular}{cll}
\hline Gene names & Primers & \multicolumn{1}{c}{ Sequences } \\
\hline \multirow{2}{*}{ GAPDH } & Sense & $5^{\prime}$-CGG AGT CAA CGG ATT TGG TCG TAT-3' \\
& Antisense & $5^{\prime}$-AGC CTT CTC CAT GGT GGT GAA GAC-3' \\
MMP-2 & Sense & $5^{\prime}$-CTT CTT CAA GGA CCG GTT CAT-3' \\
& Antisense & $5^{\prime}$-GCT GGC TGA GTA GAT CCA GTA-3' \\
MMP-9 & Sense & $5^{\prime}$-TGG GCT ACG TGA CCT ATG ACC AT-3' \\
& Antisense & $5^{\prime}$-GCC CAG CCC ACC TCC ACT CCT C-3' \\
\hline
\end{tabular}

PCR 산물에 DNA gel loading solution을 섞어서 loading 한 후 $100 \mathrm{~V}$ 에서 전기영동을 하였다. 전기영동으로 $\mathrm{DNA}$ 분리가 끝난 gel을 ethidium bromide $(\mathrm{EtBr})$ 를 이용하여 염색한 후 UV 하에서 확인하고 Picture works' photo enhancer를 이용 하여 사진 촬영을 하였다. 이때 housekeeping 유전자인 glyceraldehyde-3-phosphate dehydrogenase (GAPDH) 유전자를 internal control로 사용하였다.

\section{통계 처리}

모든 실험결과는 평균 \pm 표준편차로 표시하였고 SigmaPlot을 이용하여 Student $t$-test를 이용하여 통계적 유의성을 얻었다.

\section{결과 및 고찰}

본 연구에서는 MCF-7 및 MDA-MB-231 인체유방암세포 모 델에서 $\mathrm{TPA}$ 에 의한 침윤 촉진 및 $\mathrm{MMPs}$ 의 활성 증가에 미치 는 genistein의 영향을 비교함으로서 genistein의 암세포 전이 억제 활성 여부를 조사하였다. 이를 위하여 암세포의 침윤에 있어서 중요한 역할을 하는 것으로 알려진 MMP-2 및 -9의 활성에 미치는 genistein의 영향을 조사하기 위하여 MCF-7 및 MDA-MB-231 세포에 적정 농도의 genistein을 처리하고 60 분 후에 TPA를 처리하였다. 24시간 배양 후, 배지의 상층액 을 수거하여 gelatin zymography를 실시한 결과는 Fig. 1에 나타낸 바와 같다. 결과에서 알 수 있듯이 TPA가 단독 처리된 두 유방암세포에서는 정상 조건에서 배양된 암세포에서 보다 MMP-2 및 -9의 활성이 모두 현저히 증가되었다. 그러나 genistein이 전처리된 조건에서 배양된 유방암세포에서는 TPA 처 리군 또는 대조군에 비하여 genistein 처리 농도 증가에 따라 두 MMPs의 활성이 현저하게 억제되었음을 알 수 있었다.

다음은 Fig. 1에서 관찰된 genistein에 의한 MMP-2 및 -9의 활성억제가 그들 유전자들의 발현 억제와 연관성이 있는지의 여부를 조사하였다. 이를 위하여 $\mathrm{TPA}$ 의 단독 처리와 $\mathrm{TPA}$ 및 genistein이 동시에 처리된 배지에서 배양된 두 유방암세포를 대상으로 MMP-2 및 -9의 전사 및 번역 수준의 발현 변화를 RT-PCR 및 Western blotting을 통하여 비교하였다. Fig. 2A에 서 나타낸 바와 같이 TPA가 단독으로 처리된 배지에서 배양 된 MMP-2 및 -9의 mRNA의 발현이 genistein 동시 처리군에 비하여 현저히 높게 나타났으며, 이는 MCF-7 및 MDA-
A)

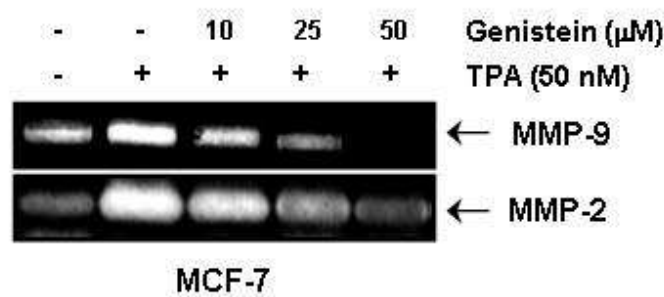

B)

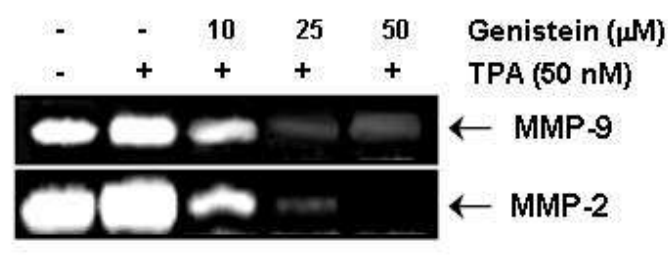

MDA-MB-231

Fig. 1. Inhibition of TPA-induced activation of MMP-9 and -2 by genistein in MCF-7 and MDA-MB-231 human breast adenocarcinoma cells. MCF-7 (A) and MDA-MB-231 (B) cells were pretreated with the indicated concentrations of genistein for $60 \mathrm{~min}$, and then they were treated with $50 \mathrm{nM}$ TPA for $24 \mathrm{hr}$. The conditioned medium was prepared and used for gelatin zymography as indicated in the Materials and Methods section.

MB-231 세포에서 동일한 현상이었다. 또한 두 MMPs의 단백 질 발현 역시 genistein이 선 처리된 유방암세포에서 TPA에 의하여 유도되는 MMP-2 및 -9의 단백질 발현에 비하여 현저 히 낮게 관찰되었다(Fig. 2B). 아울러 genistein에 의한 MMPs 의 활성 억제가 암세포의 침윤 억제와 직접적인 연관성을 가 지는지의 여부를 조사하기 위하여 TPA가 유방암세포의 침윤 성을 촉진시키는지의 여부를 먼저 조사하였다. Fig. 3A에 나타 낸 바와 같이 MCF-7 세포에서 TPA가 처리된 배지에서 배양 된 세포는 정상 배지에서 배양된 세포에 비하여 약 4 배 정도의 침윤 촉진 현상을 보였다. 그러나 genistein이 전처리된 조건 에서 $\mathrm{TPA}$ 에 의한 침윤은 거의 이루어지지 않았으며(Fig. 3A), 이러한 현상은 MDA-MB-231 세포에서도 유사하게 관찰되었 다(Fig. 3B).

이상에서 관찰된 genistein의 TPA 유도 $\mathrm{MMPs}$ 활성 및 침 윤성 증가의 억제 효과가 genistein의 세포독성 효과에 의한 
A)

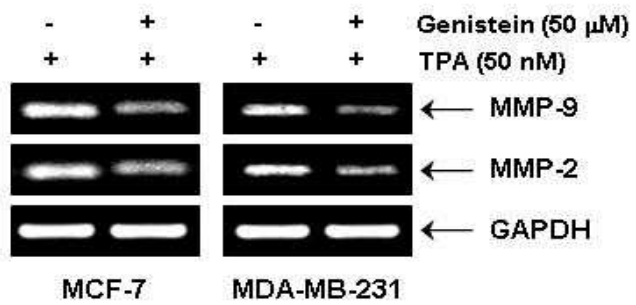

B)

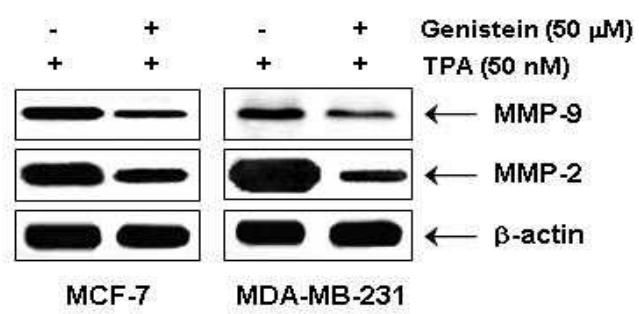

Fig. 2. Effect of genistein on TPA-induced expression of MMP-9 and -2 mRNA and proteins in MCF-7 and MDA-MB-231 cells. MCF-7 and MDA-MB-231 cells were pretreated without or with $50 \mu \mathrm{M}$ genistein for $60 \mathrm{~min}$, and then they were treated with $50 \mathrm{nM}$ TPA for $24 \mathrm{hr}$. (A) The levels of MMP-9 and -2 mRNA were determined by RT-PCR. GAPDH were used as an internal control. (B) The cells were lysed and the cellular proteins $(50 \mu \mathrm{g})$ were separated by electrophoresis on SDS-polyacrylamide gels and transferred to nitrocellulose membranes. Membranes were probed with the indicated antibodies and the proteins were visualized using an ECL detection system. Actin was used as an internal control.

A)

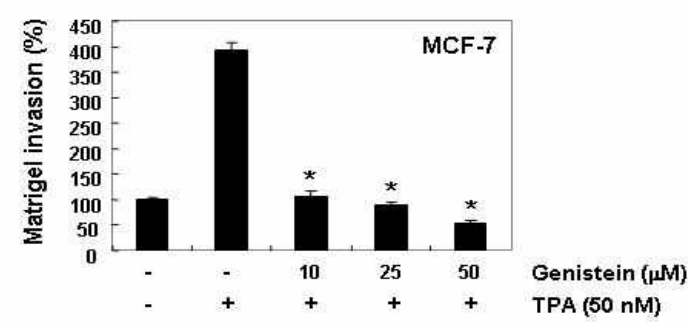

B)

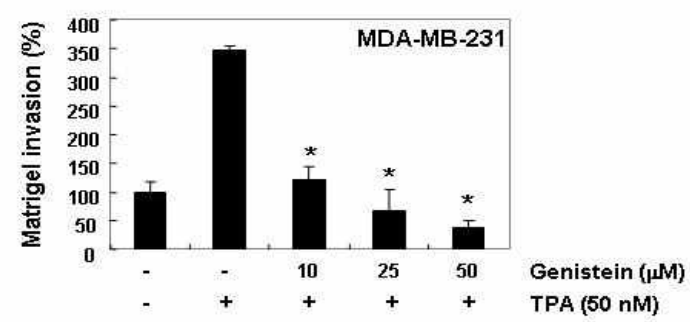

Fig. 3. Inhibition of TPA-induced cells invasion by genistein in MCF-7 and MDA-MB-231 cells. A matrigel invasion assay was carried out with genistein in the presence of TPA $(50 \mathrm{nM})$. After a $24-\mathrm{hr}$ incubation, cells on the bottom of the membranes were fixed, stained, and counted. Each value represents the mean \pm SD of the results from three independent experiments relative to the control. $p<0.05$ vs. cells treated with TPA alone.
A)

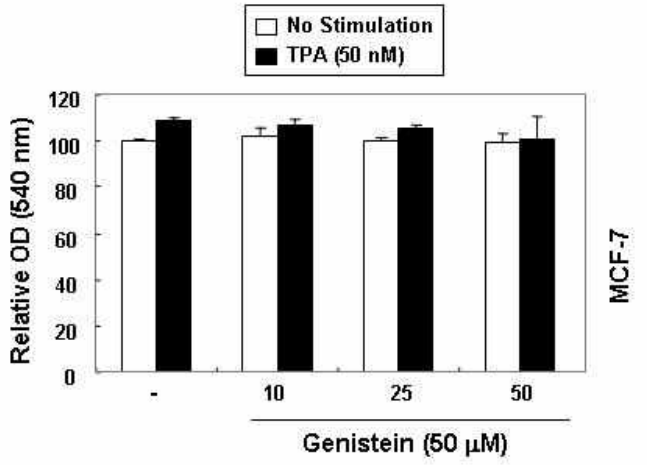

B)

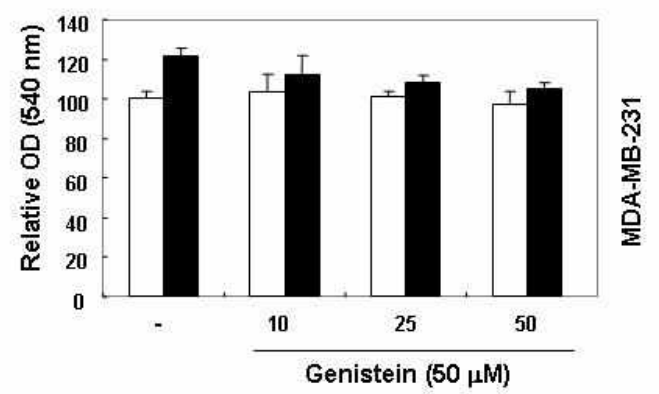

Fig. 4. Effect of genistein and TPA in cell viability of MCF-7 and MDA-MB-231 cells. MCF-7 (A) and MDA-MB-231 (B) cells grown under the same conditions as Fig. 1 were sampled and cell viability was measured using an MTT assay. Each point represents the mean $\pm \mathrm{SD}$ of three independent experiments.

것인지의 여부를 조사하였다. 이를 위하여 적정 농도의 genistein 처리 60분 후에 $\mathrm{TPA}$ 를 처리하고, 다시 24시간 배양 후 MTT assay를 실시하였다. Fig. 4의 결과에서 알 수 있듯이 $\mathrm{TPA}$ 단독 처리에 의하여 MCF-7 및 MDA-MB-231 세포 증 식이 약간 증가하였으나, 큰 유의적인 변화는 없었다. 아울러 본 실험에서 처리된 $50 \mu \mathrm{M}$ 까지의 genistein 뿐만 아니라 50 $\mathrm{nM}$ 의 $\mathrm{TPA}$ 를 동시에 처리한 조건 모두에서 정상 배지에서 배양된 세포들에 비하여 세포증식 억제 현상은 관찰되지 않 았다.

이상의 결과에서 $\mathrm{TPA}$ 에 의한 $\mathrm{MMP}-2 /-9$ 의 활성 및 침윤성 의 증가를 genistein이 효과적으로 억제하였음을 관찰하였다. $\mathrm{MMPs}$ 는 단백질 분해효소의 일종으로 그들의 억제인자인 TIMPs와의 상호작용에 의하여 세포외 기질의 항상성 유지에 중요한 역할을 하는 것으로 알려져 있다. MMPs는 신체의 결 합조직을 섬세하게 조절하는데, 태아 발달, 장기 형성, 신생혈 관 형성, 연골 개조, 뼈 성장, 각막 복구 및 상처 치료 등 다양한 과정에 참여한다. 그러나 종양, 관절염 및 심혈관 질환과 같은 병적인 상태에서는 $\mathrm{MMPs}$ 의 미세한 조절기능이 붕괴되어 광 범위한 세포외 기질의 분해 및 재구성이 유도되는 것으로 알 려져 있다[7,10,31]. 즉 정상조직에서는 MMPs와 TIMPs의 발 현이 균형을 이루고 있어 기저막의 분해 대사가 적절히 조절 
되고 있지만 종양세포에서는 $\mathrm{MMPs}$ 의 활성 증가와 함께 TIMPs의 발현 감소가 동반되어지고, 이러한 불균형에 의하여 암세포의 침윤성이 증대되어 진다[17,23]. 특히 Type IV collagenase인 MMP-2 및 -9는 금속이온을 cofactor로 요구하는 효 소로서 암세포의 전이와 침윤이 유발될 경우 기저막을 분해하 여 암세포의 전이, 침윤 및 신생혈관형성을 활성화시킴으로서 암세포 증식과 이동에 결정적인 역할을 한다[25].

본 연구의 결과에서 알 수 있듯이 genistein에 의한 MMP-2 및 -9의 활성 억제는 그들 유전자들의 mRNA 및 단백질 발현 억제와도 연관성이 있었는데(Fig. 2), 이는 genistein이 MMP-2 및 -9의 발현을 전사 수준에서 억제함으로서 그들의 효소적 활성이 저하되었음을 보여 주는 것이다. 아울러 TPA 단독 처 리에 의하여 침윤성이 증가되었던 결과(Fig. 3)는 TPA에 의한 $\mathrm{MMPs}$ 의 활성 증가에 의한 것임을 알 수 있었으며, 아울러 genistein 처리에 의한 침윤성 억제 효과는 MMPs의 활성 저하 에 의한 것임을 알 수 있었다. 또한 이러한 genistein의 유방암 세포 침윤성 차단 효과는 genistein 처리에 의한 세포독성의 증가에 의한 것이 아니었음을 MTT assay를 통하여 재확인하 였다. 따라서 genistein이 단순한 암세포의 증식억제를 통한 암예방 및 항암활성 뿐만 아니라 암세포의 전이 또한 효과적 으로 억제할 수 있음을 보여주는 것으로서, 이와 연관된 보다 구체적인 분자세포생물학적 접근 및 in vivo 연구의 필요성이 요구됨을 의미한다.

\section{감사의 글}

본 연구는 농림부 농림기술개발사업의 지원(610003-03-1SU000)에 의하여 이루어진 결과의 일부입니다.

\section{References}

1. Adlercruetz, C. H., Goldin, B. R., Gorbach, S. L., Hockerstedt, K. A. V., Watanabe, S., Hamalainen, E., Markkanen, M. H., Makela, T. H., Wahala, K. T., Hase, T. A. and Fotsis, T. 1996. Soybean phytoestrogen intake and cancer risk. J. Nutr. 125, 757S-770S.

2. Bäck, M., Ketelhuth, D. F. and Agewall, S. 2010. Matrix metalloproteinases in atherothrombosis. Prog. Cardiovasc. Dis. 52, 410-428.

3. Barnes, S. 1995. Effect of genistein on in vitro and in vivo models of cancer. J. Nutr. 125, 777S-783S.

4. Brooks, S. A., Lomax-Browne, H. J., Carter, T. M., Kinch, C. E. and Hall, D. M. 2010. Molecular interactions in cancer cell metastasis. Acta. Histochem 112, 3-25.

5. Brownson, D. M., Azios, N. G., Fuqua, B. K., Dharmawardhane, S. F. and Mabry, T. J. 2002. Flavonoid effects relevant to cancer. J. Nutr. 132, 3482S-3489S.

6. Chernov, A. V. and Strongin, A. Y. 2011. Epigenetic regulation of matrix metalloproteinases and their collagen substrates in cancer. Biomol. Concepts 2, 135-147.
7. Chetty, C., Rao, J. S. and Lakka, S. S. 2011. Matrix metalloproteinase pharmacogenomics in non-small-cell lung carcinoma. Pharmacogenomics 12, 535-546.

8. Choi, Y. H., Lee, W. H., Park, K. Y, and Zhang, L. 2000. p53-independent induction of p21 (WAF1/CIP1), reduction of cyclin B1 and G2/M arrest by the isoflavone genistein in human prostate carcinoma cells. Jpn. J. Cancer Res. 91, 164-173.

9. Choi, Y. H., Zhang, L., Lee, W. H. and Park, K. Y. 1998. Genistein-induced G2/M arrest is associated with the inhibition of cyclin B1 and the induction of p21 in human breast carcinoma cells. Int. J. Oncol. 13, 391-396.

10. Curry, T. E. Jr. and Osteen, K. G. 2001. Cyclic changes in the matrix metalloproteinase system in the ovary and uterus. Biol. Reprod 64, 1285-1296.

11. Farina, H. G., Pomies, M., Alonso, D. F. and Gomez, D. E. 2006. Antitumor and antiangiogenic activity of soy isoflavone genistein in mouse models of melanoma and breast cancer. Oncol. Rep. 16, 885-891.

12. Gruber, H. E., Ingram, J. A., Hoelscher, G. L., Zinchenko, N., Norton, H. J. and Hanley, E. N. Jr. 2009. Matrix metalloproteinase 28, a novel matrix metalloproteinase, is constitutively expressed in human intervertebral disc tissue and is present in matrix of more degenerated discs. Arthritis Res. Ther. 11, R184.

13. Hadler-Olsen, E., Fadnes, B., Sylte, I., Uhlin-Hansen, L. and Winberg, J. O. 2011. Regulation of matrix metalloproteinase activity in health and disease. FEBS J. 278, 28-45.

14. Huang, Q., Shen, H. M. and Ong, C. N. 2004. Inhibitory effect of emodin on tumor invasion through suppression of activator protein-1 and nuclear factor-kappaB. Biochem Pharmacol. 68, 361-371.

15. Huang, X., Chen, S., Xu, L., Liu, Y., Deb, D. K., Platanias, L. C. and Bergan, R. C. 2005. Genistein inhibits p38 map kinase activation, matrix metalloproteinase type 2 , and cell invasion in human prostate epithelial cells. Cancer Res. 65, 3470-3478.

16. Ismail, I. A., Kang, K. S., Lee, H. A., Kim, J. W. and Sohn, Y. K. 2007. Genistein-induced neuronal apoptosis and G2/M cell cycle arrest is associated with MDC1 up-regulation and PLK1 down-regulation. Eur. J. Pharmacol. 575, 12-20.

17. Jiang, Y., Goldberg, I. D. and Shi, Y. E. 2002. Complex roles of tissue inhibitors of metalloproteinases in cancer. Oncogene 21, 2245-2252.

18. Jin, C. Y., Park, C., Cheong, J., Choi, B. T., Lee, T. H., Lee, J. D., Lee, W. H., Kim, G. Y., Ryu, C. H. and Choi, Y. H. 2007. Genistein sensitizes TRAIL-resistant human gastric adenocarcinoma AGS cells through activation of caspase-3. Cancer Lett. 257, 56-64.

19. Jin, C. Y., Park, C., Kim, G. Y., Lee, S. J., Kim, W. J. and Choi, Y. H. 2009. Genistein enhances TRAIL-induced apoptosis through inhibition of p38 MAPK signaling in human hepatocellular carcinoma Hep3B cells. Chem Biol. Interact. 180, 143-150.

20. Jin, C. Y., Park, C., Moon, S. K., Kim, G. Y., Kwon, T. K., Lee, S. J., Kim, W. J. and Choi, Y. H. 2009. Genistein sensi- 
tizes human hepatocellular carcinoma cells to TRAIL-mediated apoptosis by enhancing Bid cleavage. Anticancer Drugs 20, 713-722

21. Kousidou, O. C., Mitropoulou, T. N., Roussidis, A. E., Kletsas, D., Theocharis, A. D. and Karamanos, N. K. 2005. Genistein suppresses the invasive potential of human breast cancer cells through transcriptional regulation of metalloproteinases and their tissue inhibitors. Int. J. Oncol. 26, 1101-1109.

22. Kupai, K., Szucs, G., Cseh, S., Hajdu, I., Csonka, C., Csont, T. and Ferdinandy, P. 2010. Matrix metalloproteinase activity assays: Importance of zymography. J. Pharmacol. Toxicol. Methods 61, 205-209.

23. Liotta, L. A., Steeg, P. S. and Stetler-Stevenson, W. G. 1991. Cancer metastasis and angiogenesis: an imbalance of positive and negative regulation. Cell 64, 327-336.

24. Lukaszewicz-Zając, M., Mroczko, B. and Szmitkowski, M. 2011. Gastric cancer - The role of matrix metalloproteinases in tumor progression. Clin. Chim Acta 412, 1725-1730.

25. Mignatti, P. and Rifkin, D. B. 1993. Biology and biochemistry of proteinases in tumor invasion. Physiol. Rev. 73, 161-95.

26. Ouyang, G., Yao, L., Ruan, K., Song, G., Mao, Y. and Bao, S. 2009. Genistein induces G2/M cell cycle arrest and apoptosis of human ovarian cancer cells via activation of DNA damage checkpoint pathways. Cell Biol. Int. 33, 1237-1244.

27. Phromnoi, K., Yodkeeree, S., Anuchapreeda, S. and
Limtrakul, P. 2009. Inhibition of MMP-3 activity and invasion of the MDA-MB-231 human invasive breast carcinoma cell line by bioflavonoids. Acta. Pharmacol. Sin 30, 1169-1176.

28. Puli, S., Lai, J. C. and Bhushan, A. 2006. Inhibition of matrix degrading enzymes and invasion in human glioblastoma (U87MG) cells by isoflavones. J. Neurooncol. 79, 135-142

29. Rowe, R. G. and Weiss, S. J. 2009. Navigating ECM barriers at the invasive front: the cancer cell-stroma interface. Annu. Rev. Cell Dev. Biol. 25, 567-595.

30. Valachovicova, T., Slivova, V., Bergman, H., Shuherk, J. and Sliva, D. 2004. Soy isoflavones suppress invasiveness of breast cancer cells by the inhibition of NF-jB/AP-1-dependent and -independent pathways. Int. J. Oncol. 25, 1389-1395.

31. Visse, R. and Nagase, H. 2003. Matrix metalloproteinases and tissue inhibitors of metalloproteinases: structure, function, and biochemistry. Circ. Res. 92, 827-839.

32. Wang, X., Li, K. F., Adams, E. and Van Schepdael, A. 2011. Matrix metalloproteinase inhibitors: a review on bioanalytical methods, pharmacokinetics and metabolism. Curr. Drug Metab. 12, 395-410.

33. Zhao, R., Xiang, N., Domann, F. E. and Zhong, W. 2009. Effects of selenite and genistein on G2/M cell cycle arrest and apoptosis in human prostate cancer cells. Nutr. Cancer 61, 397-407.

\section{초록 : 인체 유방암세포에서 TPA에 의해 유도된 matrix metalloproteinases 활성 및 침윤성 증대에 미치는 genistein의 영향 \\ 최영현 ${ }^{1} \star$ 김성옥 ${ }^{2}$ \\ (동의대학교 한의과대학 생화학교실, 대학원 바이오물질제어학과(BK21 Program). 항노화연구소 및 블루바 이오소재개발센터, ${ }^{2}$ 대구한의대학교 본초약리학교실 및 BK21 한방신약개발연구팀)}

Genistein은 대두 및 그들의 부산물에 풍부하게 존재하는 isoflavone의 일종으로 정상세포에서는 독성을 나타 내지 않는 범위에서 다양한 in vitro 및 in vivo 모델에서 암세포의 증식을 효과적으로 억제할 수 있는 천연물로 알려져 있다. 본 연구에서는 MCF-7 및MDA-MB-231 유방암세포에서 matrix metalloproteinases (MMPs)의 활성 및 발현과 침윤성에 미치는 genistein의 영향을 조사하였다. 본 연구의 결과에 의하면 genistein은 12 -Otetradecanoyl phorbol-13-acetate (TPA) 처리에 의하여 활성화된 MMP-2 및 -9의 활성을 유의적으로 차단하였으며, 이는 전사 및 번역 수준에서 MMP-2 및 -9의 발현 억제와 연관성이 있었다. 또한 matrigel invasion assay를 통하여 genistein은 두 유방암세포의 침윤성을 완벽하게 차단하였음을 관찰하였으며, 이러한 효과는 genistein의 세포독 성 효과에 의한 것이 아니었음을 알 수 있었다. 비록 in vivo 동물 실험을 통한 부가적인 연구의 필요성이 있으나, 본 연구의 결과는 genistein이 암의 전이를 억제할 수 있는 효과적인 식이 소재임을 보여주는 것이다. 